\title{
LPD SEBAGAI SUMBER BELAJAR IPS DI SMP
}

\author{
K.T.P.A.V. Putra ${ }^{1}$, I.P. Sriartha ${ }^{2}$, A.T. Atmadja ${ }^{3}$ \\ ${ }_{1,2,3}$ Program Studi Pendidikan IPS, Universitas Pendidikan Ganesha, Singaraja \\ e-mail: santhi.herma2@gmail.com ${ }^{1}$, putusriartha@gmail.com² ${ }^{2}$, anantawikrama_t_atmadja@undiksha.ac.id ${ }^{3}$
}

\begin{abstract}
Abstrak
Tujuan dari penelitian ini adalah; 1) Untuk mengetahui secara ringkas bagaimana latar belakang pendirian LPD Pakraman Sogra.; 2) Menganalisis prosedur sistem pengeloaan keuangan LPD Pakraman Sogra; 3) Untuk memahami nilai-nilai karakter apa saja yang terdapat dalam pengintegrasian LPD Pakraman Sogra pada pembelajaran IPS dikelas VII SMP N 1 Selat; dan 4) Untuk menganalisis bagaimana LPD Pakraman Sogra dapat di integrasikan ke dalam RPP IPS dikelas VII SMP N 1 Selat.

Metode yang digunakan dalam penelitian ini adalah metode penelitian kualitatif, penelitian kualitatif secara umum bisa memahami fenomena-fenomena sosial dari sudut atau perspektif Informan. Informan adalah orang-orang yang diajak wawancara, diobservasi, diminta memberikan data, pendapat, pemikiran, dan persepsinya agar dapat mendapatkan hasil penelitian yang relevan. Data penelitian ini diperoleh melalui wawancara mendalam, observasi dan studi dokumen. Data ini selanjutnya diolah melalui tiga tahapan, yaitu: 1) reduksi data, 2) penyajian data, 3) analisis data dan penarik kesimpulan berdasarkan teori yang telah ditentukan.

Hasil penelitian ini menunjukkan bahwa LPD Pakraman Sogra merupakan salah satu LPD yang bersejarah dimana meiliki kekayaan alam yang melimpah, dan mengalami perkembangan yang sangat pesat karena dapat dilihat dari latar belakang LPD Sogra dan sistem pengelolaan keuanganya, dan juga LPD Sogra memiliki nilai-nilai karakter yang dapat di integrasikan ke dalam pembelajaran IPS dikelas VII SMP N 1 Selat. LPD Pakraman Sogra dapat di integrasikan ke dalam RPP IPS dikelas VII SMP N 1 Selat, hal ini sangat berdampak positif karena bisa meningkatkan motivasi belajar dan prestasi belajar karena penggunaan sumberl belajar LPD merupakan sumber yang ada dalam kehidupan manusia sehari-hari sehingga lebih mudah dipahami.
\end{abstract}

Kata kunci: LPD; Nilai-Nilai Karakter; Nilai Kearifan Lokal; Pengayaan Sumber Pembelajaran IPS

\section{Abstract}

The aim of this research is; 1) To briefly find out the background of the establishment of LPD Pakraman Sogra.; 2) Analyzing the financial management system procedures for LPD Pakraman Sogra; 3) To understand what character values are contained in the integration of LPD Pakraman Sogra in social studies class VII SMP N 1 Selat; and 4) To analyze how LPD Pakraman Sogra can be integrated into class VII grade VII SMP N 1 Selat RPP

The method used in this research is qualitative research methods, qualitative research in general can understand social phenomena from the informant's point of view or perspective. Informants are people who are interviewed, observed, asked to provide data, opinions, thoughts, and perceptions in order to get relevant research results.

The results of this study indicate that the LPD Pakraman Sogra is one of the historical LPDs where it has abundant natural resources, and has experienced very rapid development because it can be seen from the background of the Sogra LPD and its financial management system, and also the Sogra LPD has character values that are can be integrated into social studies class VII SMP N 1 Selat. LPD Pakraman Sogra can be integrated into RPP IPS class VII SMP N 1 Selat, this has a very positive impact because it can increase learning motivation and learning achievement because the use of LPD learning resources is a source that exists in everyday human life so that it is easier to understand.

Keywords: LPD; Character Values, Local Wisdom Values; Enrichment Of IPS Sources Of Learning 


\section{PENDAHULUAN}

LPD Desa Pakraman Sogra telah mengalami kemajuan yang sangat pesat selain dari pendapatan setiap tahunya meningkat, juga nasabahnya bahkan orang dari luar desa banyak melakukan kredit di LPD Sogra. LPD Desa Pakraman Sogra bisa menjadi LPD yang sehat dalam menjalankan bisnisnya, dalam memberikan kredit kepada masyarakat bisa berjalan dengan lancar juga bisa memberikan bantuan berupa beasiswa ke pada siswa di sekolah yang berdekatan dengan LPD Sogra dan bahkan LPD ini bisa berkebang di Kecamatan Selat bahkan sampai dikenal di luar daerah Kecamatan Selat. Dapat dilihat banyak orang dari luar daerah desa pakraman Sogra dan Kecamatan Selat yang datang untuk melakukan simpan pinjam atau kredit di LPD Sogra, hal tersebut yang dapat menyebabkan LPD Sogra menjadi cepat berkembang dan di kenal oleh banyak kalangan masyarakat maupun di lingkungan Desa Pakraman maupun diluar Desa Pakraman Sogra. Apa yang menyebabkan LPD Sogra bisa cepat berkembang dan bisa mengatasi pemberian kredit dengan jangka waktu yang tepat sedangkan di Kabupaten Karangasem terdapat bnyak LPD bahkan hamper masing-masing Desa Pakraman memiliki LPD. Tetapi tidak semua LPD bisa berkembang dengan baik bahkan ada yang mengalami kebangkrutan atau kemacetan yang diakibatkan karena pengembalian kredit tidak sesuai dengan harapan. Masih terdapat kredit macet yang tinggi dan juga permasalah internal yang terjadi. Pengurus melakukan penyelewengan modal finansial dengan mengeluarkan kredit fiktif dan memberikan kredit kepada pihak-pihak yang memilliki hubungan kekerabatan kepada pengurus tanpa pencatatan. Kredit yang diberikan tanpa melakukan pencatatan ini pada akhirnya yang banyak menjadi kredit macet dan menyebabkan kerugian bagi LPD. Tetapi ada pula LPD yang mengalami kemajuan dan berkembang dengan pesat seperti halnya LPD Sogra.

Menurut Suartana (2010:19) peran badan pengawas internal secara aktif mengawasi kebijakan, operasional dan praktik akuntansi dan pelaporan keuangan dan menjadi penghubung antara pengelola dengan auditor eksternal bila diperlukan. Peranan badan pengawas internal sebagai pengawas internal sangat strategis, di samping sebagai auditor internal juga sebagai partner yang bersinergi untuk memajukan LPD. Peran badan pengawas intern dalam mengawasi operasional LPD bisa dilakukan oleh siapa saja di desa pakraman bersangkutan tanpa mengenal jenjang dan jenis pendidikan. Semakin besar asset LPD maka ruang lingkup pengawasan menjadi semakin luas dan kompleks, dengan sendirinya memerlukan pengetahuan dan kompetensi yang semakin khusus. Mengingat pentingnya peranan badan pengawas intern, maka ia harus memiiki kejelasan dalam struktur organisasi yang ada, keahlian teknis, dan pola pikir yang membuat mampu menjalankan tata kelola, bimbingan, dan tanggung jawab.

Sesuai dengan pasal 1 ayat 11 Perda No.3 tahun 2007, yang dimaksud dengan pengawas internal adalah badan pengawas yang dibentuk oleh desa dan bertugas melakukan pengawasan terhadap pengelolaan LPD. Ketua badan pengawas yang dijabat oleh bendesa adat dimaksudkan untuk menciptakan suatu lingkungan pengendalian yang kondusif dan efektif. Bendesa adat diyakini mempunyai karisma dan pengaruh yang kuat di lingkungan desa pakraman sehingga akan berpengaruh terhadap lingkungan pengendalian. Bendesa adat juga dituntut untuk mengetahui secara utuh operasional LPD dan tingkat kemajuan yang dicapai, sebagai contoh bendesa adat juga ikut dalam menandatangani surat perjanjian kredit. Pendekatan yang dapat dilakukan dalam menjalankan pengawasan diantaranya adalah audit. Audit yang dilakukan oleh karyawan dalam perusahaan atau kesatuan ekonomi disebut dengan audit intern.

Dengan adanya fenomena-fenomena yang terjadi, maka sangat diperlukan adanya struktur pengendalian internal yang memadai dalam operasional LPD. Pengendalian internal yang baik ini akan sangat membantu Lembaga Perkreditan Desa dalam menghindari adanya fraud atau kecurangan-kecurangan yang akan merugikan nasabah serta citra Lembaga Perkreditan Desa itu sendiri. Setiap usaha dibangun dengan harapan usaha tersebut memiliki keberlangsungan usaha, keberlangsungan usaha (going corcern) akan dapat membuktikan bahwa Lembaga Perkreditan Desa tersebut memliki pengendalian internal yang memadai. 
Penelitian ini difokuskan pada bagaimana LPD Desa Pakraman Sogra bisa mengalami kemajuan dan perkembangan yang pesat dan pengendalian internal dalam meminimalisasi adanya kredit macet, sehingga keberlangsungan usaha dari LPD Desa Pakraman Sogra dapat tercapai. Bercemin dari keunggulan dan Keunikan LPD Pakraman Sogra jika melihat permasalahan penelitian di SMP N 1 Selat maka LPD Pakraman Sogra bisa dijadikan sebagai sumber belajar IPS yang dapat disisipkan di materi kelas VII semester ganjil. Mengingat lokasi Sekolah dan LPD sangat berdekatan maka Guru IPS yang ada di SMP N 1 Selat dapat menyisipkan pengetahuan dan sumber belajar mengenai LPD pada materi Lembaga keuangan dengan memberikan penugasan observasi ke LPD langsung yang bertujuan untuk mengetahui peranan LPD, Aktivitas LPD dan pengelolaan LPD yang dapat disandingkan dengan Bank yang sering dibahas dan ditonjolkan pada materi IPS khususnya dalam materi Lembaga Keuangan. Sebagaimana yang diketahui materi-materi pada pembelajaran IPS hanya bermuatan Nasional hanya beberapa mengangkat muatan lokal, seperti permasalahan sebagian besar siswa-siswi di jenjang SMP belum memahami dan mengetahui secara detail apa itu LPD dan peranannya. Disekolah juga murid hanya mengetahui dari sumber belajar buku LKS dan buku paket yang membahas satu lembaga keuangan salah satunya yaitu Bank dan tidak menyisipkan lembaga keuangan lainnya seperti LPD yang lebih dekat dengan lingkungan siswa di desa, sehingga jika hal ini dibiarkan maka pemahaman akan LPD akan memudar dan guru IPS perlu melalukan inovasi untuk menyisipkan LPD pada sumber belajar siswa. Dengan adanya sumber LPD pada pembelajaran IPS secara umum akan mempengaruhi wawasan dan pemahaman akan lembaga keuangan dan guru bisa mengambil beberapa nilai-nilai karakter yang tersisipkan pada LPD.

Dalam proses pembelajaran diperlukan juga penerapan pendidikan karakter yang pada dasarnya bertujuan utama untuk membangun bangsa yang tangguh, dimana masyarakatnya berakhlak mulia, bermoral, bertoleransi, dan bergotong-royong. Untuk mencapai tujuan tersebut maka di dalam diri peserta didik harus ditanamkan nilai-nilai pembentuk karakter yang bersumber dari Agama, Pancasila, dan Budaya. Mengingat pendidikan karakter sangat penting dalam pendidikan maka dengan melakukan inovasi dan pengintegrasian LPD pada pembelajaran IPS maka guru bisa memberikan beberapa nilainilai karakter yang terselip pada pengintegrasian LPD, salah satunya adalah kejujuran. Dimana nilai kejujuran ini bisa dipaparkan pada LPD saat bendahara mengelola keuangan dari setiap adanya transaksi. Jadi disini dengan memberikan nilai karakter kejujuran maka siswa-siswi bisa mengimplementasikannya pada kehidupan nyata saat mengelola uang yang mereka miliki secara jujur.

Dari penelitian terkait dengan sumber belajar IPS ditemukan kebanyakan hasil penelitian IPS saat ini membahas mengenai budaya/tradisi, tempat bersejarah, Metode pembelajaran IPS, kearifan sosial dan interaksi sosial sebagai sumber dan media pembelajaran IPS, seperti hasil penelitian Kadek Ermanda Kurniawan yang dilakukan pada Tahun 2015 dalam tesisnya dia mengunggkap mengenai Pemanfaatan Makam Keramat Karang Rupit Syeikh Abdul Qadir Muhammad (The Kwan Lie) Untuk Pengayaan Materi Pembelajaran Ips Di Kelas VII. Hasil penelitian dari Kadek Ermanda bermaksud menggunakan tempat bersejarah sebagai bahan ajar IPS yang dalam buku tidak disisipkan materi tersebut sehingga bermanfaat untuk menambah wawasan dan pengetahuan siswa pada umumnya. Penelitian lain yang berhubungan IPS adalah Pengaruh Pendekatan Saintifik Dalam Pembelajaran IPS Terhadap Sikap Sosial Dengan Kovariabel Intensitas Hubungan Dalam Pola Asuh Keluarga Pada Siswa Kelas IV SD Perkotaan yang diteliti oleh Kadek Ade Puspitarini, hasil penelitian mengungkap adanya perbedaan sikap sosial antara kelompok siswa yang mengikuti pendekatan saintifik dengan kelompok siswa yang mengikuti pendekatan pembelajaran konvensional pada siswa kelas IV SD perkotaan yang secara tidak langsung mempengaruhi pencapaian kualitas proses dan produk hasil belajar siswa dalam pembelajaran IPS.

Penelitian berikutnya yaitu Triani Widyanti dengan judul Penerapan Nilai-Nilai Kearifan Lokal Dalam Budaya Masyarakat Kampung Adat Cireundeu Sebagai Sumber Pembelajaran IPS pada Tahun 2014. Dalam penelitian ini Triani mengungkap bahwa implementasi atau 
penerapan nilai-nilai kearifan lokal suatu masyarakat dalam pembelajaran IPS menjadi bagian yang dapat merubah paradigma belajar IPS yang dinilai membosankan, monoton, menjadi pembelajaran menyenangkan dan bermakna. Selain itu, pembelajaran IPS yang bersumber pada nilai-nilai kearifan lokal diharapkan mampu memberikan wawasan dan pencerahan bagi peserta didik untuk memacu kreatifitas mereka dalam menghadapi masa depan yang akan menuntut mereka untuk dapat berkompetisi atau bersaing dengan masyarakat lain dalam era global. Dari hasil penelitian yang telah dibaca mengenai pendidikan IPS, kebanyakan judul penelitian yang diangkat dan diteliti hanya seputaran ituitu saja tanpa ada pembaharuan, walaupun sama akan tetapi hanya mengubah variable dan objek penelitiannya saja. Secara umum maksud penelitian yang dilakukan oleh peneliti di atas mempunyai konsep dan manfaat yang bagus dalam pengembangan pendidikan IPS di Indonesia karena penelitian ini mengangkat hal yang unit dan menarik untuk dikaji dalam pembelajaran IPS. Untuk melakukan inovasi dan pembaharuan dalam pembelajaran IPS disini peneliti tertarik mengangkat tema dan bahan ajar IPS yang lain dari pada penelitian diatas, hal ini dilakukan untuk menambah dan membuat inovasi baru dalam pembelajaran IPS di Indonesia. Disini peneliti menggunakan bahan ajar IPS dengan menggunakan objek penelitian LPD, mengingat LPD merupakan salah satu lembaga keuangan tradisional.

\section{METODE}

Rancangan penelitian yang digunakan dalam penelitian ini adalah metode penelitian kualitatif. Menurut Sukmadinata (2000: 94), penelitian kualitatif ditujukan untuk memahami fenomena-fenomena social dari sudut atau perspektif partisipan. Partisipan adalah orangorang yang diajak wawancara, diobservasi, diminta memberikan data, pendapat, dan pemikirannya tentang data yang diketahuinya. Penelitian kualitatif memiliki strategi-strategi yang bersifat interaktif, seperti observasi langsung, observasi partisipatif, wawancara mendalam, dokumen-dokumen, Teknik pelengkap seperti foto, rekaman, dan lain-lain. Metode ini digunakan untuk mendukung penelitian yang mengkaji LPD Sogra sebagai sumber belajar IPS di SMP kelas VII. Penelitian ini memaparkan makna, arti, dan fungsi dari data yang di dapat oleh pelaku (informan).

Disamping itu penelitian ini juga dapat dikatakan penelitian kualitatif etnografi. Hal tersebut disebabkan oleh beberapa alasan yaitu tuntutan kebutuhan manusi sebagai mahkluk sosial terus berkembang sejalan dengan perkembangan kehidupan, penemuan dibidang teknologi dan inovasi, dan juga didorong oleh rasa ingin tahu, para peneliti juga didorong oleh adanya tuntutan praktis dilapangan.

Etnografi adalah suatu deskripsi dan analisa tentang suatu masyarakat didasarkan pada penelitian lapangan sebagai data dalam penelitian, etnografi menyajikan data-data yang bersifat hakiki. Menurut Muhadjir (2007: 47) penelitian etnografi adalah suatu deskripsi mengenai cara berpikir, hidup dan berperilaku suatu masyarakat. penelitian etnografi adalah penelitian dengan menggunakan pengamatan dan partisipasi peneliti di dalam kelompok masyarakat tertentu. Penggunaan etnografi dalam penelitian ini mengingat fokus utama dalam penelitian ini adalah menjelaskan dan mendeskripsikan secara detail tentang nilai-nilai yang ada dalam LPD juga pentingnya LPD, kegunan LPD dan dampak positif LPD bagi masyarakat dimasukan kedalam sebuah materi pembelajaran IPS di SMP Negeri 1 Selat yang dapat disisipkan di materi kelas VII semester ganjil. Mengingat lokasi sekolah dan LPD berdekatan maka Guru IPS yang ada di SMP Negeri 1 Selat dapat menyisipkan pengetahuan dan sumber belajar mengenai LPD pada materi Lembaga keuangan dengan memberikan penugasan observasi ke LPD langsung yang bertujuan untuk mengetahui peranan LPD, atktivitas LPD dan pengelolaan LPD yang dapat disandingkan dengan bank yang sering dibahas dan ditonjolkan pada materi IPS khususnya dalam materi Lembaga keuangan.

Dalam pembelajaran IPS di SMP tersebut, khususnya pada kelas VII terdapat permasalahan dalam pembelajaran IPS seperti, siswa belum mengetahui adanya keberadaan LPD, buku paket yang materi didalamnya bersumber pada materi nasional, guru menggunakan model pembelajaran yang monoton seperti tanya jawab, ceramah dan pembagian kelompok dan permasalahan terakhir dalam pembelajaran IPS adalah belum 
adanya pemahaman dari siswa tentang pembelajaran IPS yang bersumber dari materi lokal atau lingkungan sekitar. Dari sinilah peneliti mempunyai inisiatif untuk menggunakan LPD Sogra sebagai sumber pembelajaran IPS.

\section{HASIL DAN PEMBAHASAN}

\section{Latar Belakang Pendirian LPD Pakraman Sogra}

Secara kronologis awal terbentuknya LPD Desa Pakraman Sogra didirikan berdasarkan SK Gubernur Bali No: 619/1995 Tanggal 13 Nopember 1995 dan SK Bupati Karangasem No 121 Th 1996 Tanggal 23 Februari 1996. Tujuan utama didirikan LPD adalah membantu peningkatan perekonomian warga desa adat, meberantas ijon dan lain-lain sejenis. Sebelum dioperasikan LPD Desa Pakraman Sogra pertama kali diawali dengan paruman seluruh prajuru desa adat sogra yang mengambil tempat di Bale Agung Pura Puseh Sogra sejak Tanggal 16 Februari 1996 s/d 11 Juli 2005. Pada saat didirikan, modal awal LPD Desa Pakraman Sogra bersumber dari bantuan Pemda Tk.I Bali sebesar Rp. 6.329.500 yang mana Rp 5.000.000 untuk modal awal dan Rp 1.329 .500 berupa inventaris. Sampai dengan akhir tahun 2016, modal tahun buku 2016 sudah berkembang menjadi Rp 5.000.000.000 dengan total asset Rp 69.349.951.000. Kantor LPD Desa Pakraman Sogra beralamat dijalan jurusan Pura Pasar Agung Besakih Giri Tolangkir tepatnya di Banjar Sogra Desa Sebudi Selat Karangasem, mulai ditempati tanggal 11 Juli 2005, yang dlunya berkantor dibalai banjar sogra Desa Sebudi dimana tempat tersebut juga menjadi satu dengan secretariat pura pasar agung yang berdiri diatas tanah dengan sistem sewa atau kontrak selama 25 tahun semenjak 11 Juli 2005 s/d 11 Juli 2030 seluas kurang lebih 10 are yang mana dana pembangunan dan kontrak tersebut bersumber dari LPD Sogra dan bantuan Pura Pasar Agung Sebesar Rp. 10.000.000 dan pada Tahun 2013 LPD Sogra selesai Merenopasi Kantor dengan Anggran 1,1 Miliyar yang bersumber dari dana inventaris LPD.

Diihat dari mulai operasinya LPD Desa Pakraman Sogra dari tanggal 16 Februari 1996 sampai 31 desember 2019 menunjukan grafis perkembangan semakin tahun semakin meningkat. Grafik perkembangan ini terbukti dari perkembangan asset yang semula pada tahun 1996 hanya Rp 6.329.500 sampai akhir tahun 2019 sudah mencapai Rp 63.349.860.000. Secara umum perkembangan LPD Desa Pakraman Sogra termasuk kriteria yang sehat sesuai dengan ketentuan Acuan Kesehatan yang dikeluarkan BPD dan LPLPD yang menggunakan Metode CAMEL dengan Secor sebesar87,62 dari minimal ketentuan secor LPD 81,00.

Lembaga Perkreditan Desa (LPD) Sebagai salah satu lembaga Keuangan milik Desa Pakraman telah menunjukkan peranannya dalam mendorong pembangunan ekonomi pedesaaan, menciptakan kesempatan berusaha dan peluang kerja bagi masyarakat desa serta berperan dalam menunjang sebagai salah satu lembaga keuangan mikro, LPD selama ini masih tetap eksis dan mampu bersaing dengan lembaga keuangan lainnya termasuk Bank. Dalam sejarah berdirinya LPD di Desa Sebudi terdapat lika-liku perjuangan dan hambatan yang dihadapi hingga saat ini LPD ini tetap eksis, Berikut adalah hasil observasi dan wawancara dengan Kepala LPD Desa Pakraman Sogra yakni Bapak I Wayan Putra mengenai pembahasan mengenai berdirinya LPD di Desa Sebudi:

"LPD Desa Pakraman Sogra berdiri dan resmi beroperasional pada pada Tanggal 13 Nopember 1995 berdasarkan SK Gubernur dan SK Bupati dan Perda LPD. Pendirian ini di gagas oleh Almarhum Ida Bagus Mantra yang merupakan mantan Gubernur Bali yang pada saat itu memerintahkan Bapeda Bali untuk Seminar di Semarang setelah sekembalinya dari seminar Gubernur Bali berkeinginan untuk mendirikan LPD yang sekiranya dipergunakan dan dikelola oleh adat. LPD di bali sebenarnya sudah beropersi dan ada sekitar tahun 1984 akan tetapi disini LPD Pakrman Sogra mulai beroperasional pada tahun 1995 karena keberhasilan dari pilot project yang ada diberbagai Kabupaten". ( Hasil wawancara dengan Bapak Kepala LPD Pakraman Sogra Pada Tanggal 8 Nopember 2020)

Hal ini juga diperkuat oleh lbu Wayan Suriasih selaku Petengen di LPD Pakraman Sogra dalam hasil observasi dan wawancara sebagai berikut: 
“LPD Desa Pakraman Sogra didirikan karena dipengaruhi oleh beberapa faktor yakni karena program pemerintah daerah, karena kebutuhan krama desa dan Kuranngnya Lembaga keuangan. Pencetus LPD Alm Prof Dr Ida Bagus Mantra, pengurus saat didirikan LPD Sogra I Wayan Putra. (Hasil wawancara dengan Bapak Bendahara LPD Pakraman Sogra Pada Tanggal 8 Nopember 2020)

Dari pemaparan informan dan paparan mengenai sejarah LPD di Desa Sebudi maka dapat disimpulkan bahwa LPD Pakraman Sogra merupakan LPD yang bersejarah karena memerlukan perjuangan yang sangat keras untuk berkembang dan menghadapi permasalahan yang sulit dan menentukan masa depan LPD itu sendiri. Saat ini LPD Desa Pakraman Sogra memiliki perkembangan yang sangat luar biasa hingga mampu bersaing dengan LPD lain yang ada di Kecamatan Selat bahkan dengan lembaga-lembaga keuangan lainya seperti Bank. Perkembangan jumlah dan volume usaha LPD di Desa Sebudi dari waktu ke waktu menunjukkan bahwa keberadaan LPD memang dibutuhkan oleh masyarakat di Desa Sebudi, selain LPD bisa membantu didalam pemberian modal kredit, LPD juga membantu mensejahterahkan dan memakmurkan rakyat melalui perekonomian yang dijalankan. Oleh karena itu LPD Pakraman Sogra memiliki peran yang sangat strategis dalam mendorong pembangunan perekonomian pedesaan secara mengglobal.

\section{Sistem Pengelolaan Keuangan di LPD Pakraman Sogra}

Sistem pengelolaan keuangan LPD pakraman sogra hampir sama dengan sistem pengelolaan keuangan pada LPD-LPD yang ada di Bali tentunya sistem pengelolaan keuangan dimulai dari melakukan analisis pemberian kredit dan calon pemimjam atau debitur telah di setujui oleh LPD Pakraman Sogra, maka LPD Pakraman Sogra akan memberikan kredit sesuai kebutuhan dan jaminan yang diberikan. Pada tahap pertama ini, prosedur pengelolaan keuangan bermula dari penerimaan kas. Yang mana aktivitas terakhir dalam siklus pendapatan berkaitan dengan penerimaan kas. Fungsi kasir akan melaporkan penerimaan, menangani remittance pelanggan, dan menyetorkan uang ke bank. Aktivitas terakhir dalam penerimaan kas yaitu mencatat penerimaan kas dengan pembuatan jurnal penerimaan kas secara over-the-counter dan melalui pos serta posting penerimaan kas melalui pos ke akun pelanggan. Dari kedua penjelasan ini, dapat ditarik kesimpulan bahwa penerimaan kas adalah aktivitas terakhir dalam siklus pendapatan yaitu dengan mencatat penerimaan kas dengan pembuatan jurnal, melaporkan penerimaan, menangani remittance pelanggan, dan menyetorkan uang ke bank. Penerimaan kas terjadi karena masyarakat di Desa Sebudi melakukan deposito maupun menabung. Pada langkah ini nasabah melakukan transaksi yang nominalnya tergantung dari jumlah yang ingin dikeluarkan dalam melakukan deposito dan tabungan. Disini pegawai LPD melakukan pencatatan pada dokumen berupa kitir kredit, membuat nominal di buku tabungan dan menginputnya dalam bukti kas masuk dan terakhir didistribusikan dan membuat bukti serah terima yang bertujuan melakukan rekonsiliasi antara jumlah saldo yang ada di LPD Pakraman Sogra dengan saldo yang ada di tabungan nasabah.

\section{Nilai-Nilai Karakter yang Terdapat Dalam Pengintegrasian LPD Pakraman Sogra Pada Pembelajaran IPS di SMP Negeri 1 Selat}

Pendidikan di Indonesia membutuhkan pendidikan yang membentuk karakter peserta didiknya sesuai dengan karakter yang telah diwariskan oleh budaya lokal yang telah ada sejak zaman dahulu. Maka dari itu, Lembaga pendidikan di Indonesia dapat menerapkan pendidikan yang berbasis pada local wisdom (kearifan lokal). Kearifan lokal merupakan produk budaya masa lalu yang patut secara terus-menerus dijadikan pegangan hidup. Meskipun bernilai lokal tetapi nilai yang terkandung didalamnya sangat universal.

Secara formal, peningkatan mutu Pendidikan dalam pelaksanaan Pendidikan di lingkungan sekolah, banyak bergantung kepada aktivis belajar siswa dalam memanfaatkan lingkungan belajarnya. Penyelenggaraan proses pembelajaran di lingkungan sekitar sekolah dan lingkungan masyarakat memiliki peran yang sangat penting bagi siswa dalam pembelajaran IPS, memiliki peran yang esensial dan strategis terhadap pembinaan dan peningkatan kemampuan untuk mencapai tujuan Pendidikan. 
Untuk memperoleh hasil belajar yang optimal peserta didik dituntut tidak hanya mengandalkan dari apa yang didapatkan di dalam kelas tetapi juga harus bisa mempelajari dan menelusuri aneka ragam sumber belajar yang diperlukan dari lingkungan luar sekolah atau masyarakat. Adapun menurut Sri Khanifah (2011:28) dalam jurnalnya yang berjudul "Pemanfaatan lingkungan sekolah sebagai sumber belajar untuk meningkatkan hasil belajar siswa materi klasifikasi makhluk hidup di MTS Miftahul Huda Bogorejo" menyatakan bahwa pembelajaran dengan pemanfaatan lingkungan sekolah sebagai sumber belajar materi klasifikasi makhluk hidup pada kelas VII MTs dapat meningkatkan hasil belajar siswa (aspek kognitif, afektif, psikomotorik) yang ditunjukan dengan adanya peningkatan hasil belajar pada setiap siklus.

Adapun jurnal dari Laely Armiyati (2013) yang berjudul "Nilai-nilai kearifan local masyarakat adat kampung naga sebagai alternatif sumber belajar" mengungkapkan bahwa nilai-nilai yang muncul dalam kearifan local masyarakat kampung Naga adalah mencintai lingkungan, gotong royong, kebersamaan, kesederhanaan dan kesetaraan, interaksi social, kreatif, kemandirian, tanggung jawab, dan berprinsip. Nilai-nilai tersebut cocok dengan KI dan KD pada kelas VII dan kelas VIII dengan deikian kearifan local masyarakat adat kampung Naga dapat menjadi sumber pembelajaran alternatif bagi siswa SMP, terutama dalam pembelajaran IPS. Menurut I Putu Gede Anom (2014) dalam jurnal yang berjudul "Museum perjuangan margarana sebagai sumber belajar IPS di kelas IX (studi kasus SMPN 1 Marga)" menyatakan bahwa koleksi yang ada di Museum Perjuangan Margarana yang dapat dijadikan sebagai sumber belajar IPS terpadu berupa senjata-senjata, alat-alat penyamaran, alat medis, alat komunikasi, perlengkapan pemuda pejuang. Manfaat Museum Perjuangan Margarana sebagai sumber belajar bagi siswa di SMPN 1 Marga yaitu siswa dapat belajar secara mandiri melalui pengamatan langsung dengan melihat koleksi-koleksi yang berada di dalam Museum tersebut. Makna dari hasil penelitian dari Laely Armiyati dan I Putu Gede Anom adalah sebagai bukti penelitian yang sejenis untuk menjawab semua bentuk persoalan yang ada terutama pengembangan Pendidikan karakter dalam Pendidikan IPS bawasanya dengan pemanfaatan lingkungan sekitar sekolah dan siswa sebagai sumber utama materi pengayaan dalam pembelajaran IPS merupakan sebuah kewajiban mengingat laboratorium IPS adalah masyarakat dan lingkungan sekitarnya.

Hasil pemantauan menunjukan bahwa sebagian besar guru-guru masih belum paham benar akan pembelajaran yang berbasis kompetensi dan pembelajaran melalui pendekatan konstektual, baik konsep maupun penerapannya. Kondisi demikian dipengaruhi oleh beberapa faktor-faktor antara lain, terbatasnya rujukan atau bahan pustaka yang sesuai dengan kebutuhan guru, rendahnya kemauan sebagian besar besar untuk meningkatkan pengetahuan akademis dan profesionalnya, dan kurang terpadunya pembinaan guru oleh lembaga-lembaga.

Dengan menerapkan pendidikan berbasis pada kearifan lokal maka peserta didik diharapkan akan mampu menciptakan pendidikan yang memberi makna bagi kehidupan manusia Indonesia, Artinya pendidikan mampu menciptakan generasi-generasi muda yang mampu melestarikan dan mencintai budaya sendiri. Selain itu, pendidikan harus mampu membentuk karakter manusia yang berintegritas tinggi dan berkarakter sehingga mampu melahirkan tunas-tunas bangsa yang hebat dan bermartabat sesuai dengan spirit pendidikan yaitu memanusiakan manusia.

Prospek kearifan lokal sangat bergantung kepada bagaimana masyarakat melestarikan kembali kearifan lokal yang ada dan bagaimana masyarakat mengubah pola pikirnya kembali ke pola holistic. Sehingga sumber daya alam dan lingkungan alam yang dimiliki masyarakat dapat dimanfaatkan dan dilestarikan dengan tanpa mengganggu keseimbangannya. Dampak pengintegrasian LPD Pakraman Sogra sebagai lembaga keuangan terhadap pembelajaran IPS dikelas VII SMP N 1 Selat berbasis kearifan lokal adalah adanya nilai-nilai karakter yang dapat dipetik dari adanya LPD Pakraman Sogra yang merupakan salah satu lembaga keuangan yang kini peranannya dan keberadaanya masih sangat sedikit mengetahui.

Nilai-nilai karakter dari LPD Pakraman Sogra sebagai lembaga keuangan tradisional di Desa Sebudi dapat dijadikan sebagai pembelajaran IPS berbasih kearifan lokal di SMP 
adalah diimplementasikan melalui pendidikan karakter yang memuat nilai-nilai yang perlu ditanamkan, ditumbuhkan dan dikembangkan kepada setiap peserta didik.

Nilai-nilai yang dikembangkan tersebut tidak lepas dari budaya bangsa. Budaya bangsa merupakan sistem nilai yang dihayati, diartikan sebagai keseluruhan sistem berpikir tentang tata nilai, moral, norma dan keyakinan manusia yang dihasilkan masyarakat.

Berdasarkan hasil wawancara dengan beberapa siswa di SMP N 1 Selat terdapat beberapa makna yang diungkapkan dari mengintegrasikan LPD Pakraman Sogra dalam Pembelajaran IPS. Salah satu siswa tersebut adalah bernama Ni Komang Wina Triana Karang (14 Tahun) yang berasal dari Desa Sebudi dia mengungkapkan bahwa setelah mengamati peranan Bank dan LPD yang hampir sama dia memaparkan kesimpulan bahwa disana terdapat penggalan nilai karakter yang berupa nilai Gotong- royong yang terdapat pada saat mengamati peranan LPD Pakraman Sogra. Sedangkan siswa lainnya yakni Komang Puja Astuti (14 Tahun) memiliki pendapat yang hampir sama, ia menyatakan bahwa ketika nilai karakter yang ditemukan dalam pengintegrasian LPD Ambengan adalah sikap Disiplin, jujur dan peduli sosial.

Pendapat lain diungkapkan oleh guru pengampu mata pelajaran IPS di kelas VII SMP N 1 Selat, Pak Kadek Ariarta dalam hasil observasi dan wawancara, Beliau menyatakan bahwa nilai karakter banyak kita petik dalam pengintegrasian LPD Pakraman Sogra ke dalam pembelajaran IPS misalkan sikap disiplin, gotong-royong, kerja keras dan nilai pedui terhadap lingkungan.

\section{SIMPULAN DAN SARAN \\ Simpulan :}

1. Mengetahui latar belakang dari LPD Pakraman Sogra yang merupakan LPD yang bersejarah karena LPD Pakraman Sogra adalah lembaga keuangan tradisional yang sangat unik dan berbeda dengan daerah lain yang ada di Bali. Hal tersebut didasari atas kenyataan dilapangan bahwa masyarakat Sebudi mempunyai LPD yang sangat berkembang dan maju di daerah tersebut dimana perkembangan LPD Pakraman Sogra dipengaruhi oleh aturan berupa awig-awig desa dan didukung oleh tingkat kepercayaan masyarakat. Desa Sebudi merupakan salah satu desa tua yang ada di Kabupaten Karangasem serta Desa Sebudi memiliki SDA yang melimpah utamnya didalam pengelolaan keuangan pada LPD Pakrman Sogra seperti bahan galian C dan objek pariwisata.

2. Memahami sistem pengelolaan LPD Desa Pakraman Sogra dalam menjalankan kegiatan usahanya sehingga saat ini LPD Pakraman Sogra memiliki perkembangan yang sangat luar biasa hingga mampu bersaing dengan LPD lain yang ada di Desa Sebudi bahkan dengan lembaga-lembaga keuangan lainya seperti Bank. Perkembangan jumlah dan volume usaha LPD di Desa Sebudi dari waktu ke waktu menunjukkan bahwa keberadaan LPD memang dibutuhkan oleh masyarakat di Desa Sebudi, selain LPD bisa membantu didalam pemberian modal kredit, LPD juga membantu mensejahterahkan dan memakmurkan rakyat melalui perekonomian yang dijalankan. Oleh karena itu LPD Pakraman Sogra memiliki peran yang sangat strategis dalam mendorong pembangunan perekonomian pedesaan secara mengglobal.

3. Memahami nilai-nilai karakter yang terdapat pada LPD Sogra di integrasikan ke pembelajaran IPS Dampak dari adanya pengintegrasian LPD Pakraman Sogra terhadap pembelajaran IPS adalah mengenalkan sekaligus mempertahankan peranan dan keberadaan LPD Pakraman Sogra pada masyarakat setempat maupun pada siswa dan siswi di SMPN 1 Selat, mengingat keberadaan dan peranan LPD makin terkikis karena pendalam lembaga keuangan adalah Bank saja, disisi lain penanaman akan lembaga keuangan yang tertera pada buku pembelajaran baik pada LKS dan buku paket hanya menjelaskan lembaga keuangan adalah Bank saja. Pengintegrasian ini juga.

4. Menganalisis LPD Pakraman Sogra di integrasikan melalui RPP IPS kelas VII di SMP Agar nilai-nilai karakter dan nilai kearifan lokal yang ada di Bali semakin berkembang 
ditengah-tengah masyarakat Desa Sebudi tidak terbuang secara percuma dan sia-sia atau sampai terkikis oleh kemajuan zaman, maka nilai tersebut harus diintegrasikan dalam pendidikan. Pendidikan yang dimaksud dapat dilakukan dalam keluarga, masyarakat dan sekolah. Khusus pada bangku sekolah, pengintegrasian nilai-nilai karakter berbasis kearifan lokal ini, dapat dilakukan pada mata pelajaran IPS tingkat SMP. Caranya adaalah dengan jalan menyeleksi KD pada silabus, kemudian memilih tema atau materi yang relevan pada buku ajar IPS. Dari situ, barulah guru mengintegrasikan nilai tersebut yang dituangkan kedalam RPP dengan menggunakan metode yang inovatif. Guru dapat menjadikan LPD Pakraman Sogra yang berdampingan dengan SMPN 1 Selat sebagai materi pembelajaran yang dipadukan dengan buku. Interaksi dan pengintegrasian ini dapat dijadikan pengamatan dilihat dari proses aktivitas LPD didalam melayani simpan pinjam di Desa Sebudi. Sehingga dari hasil pengamatan tersebut siswa dapat menggali nilaiSaran : nilai karakter dan mengaplikasikannya dalam kehidupan nyata dan sehari-hari.

1. Guru IPS

Mata pelajaran IPS tidak dapat dilepaskan dari masyarakat, oleh sebab itu disarankan bagi guru IPS pada jenjang SMP dalam proses pembelajaran,cobalah mencari sumber materi atau contoh-contoh peristiwa konstektual yang dekat dengan lingkungan siswa. Masyarakat yang merupakan Labnya IPS sesungguhnya sangat kaya akan sumber materi. Tinggalkan gaya pengajaran konvensional yang hanya mengandalkan sumber materi dari buku. Model semacam ini hanya akan membuat proses belajar tidak bermakna. Oleh sebab itu, saat ini guru kreatif dan inovatiflah yang dibutuhkan dalam mengajarkan pelajaran IPS.

2. Masyarakat Setempat

Bagi masyarakat Desa Sebudi yang memiliki LPD Pakraman Sogra seharusnya turut menjaga keberadaan dan peranan LPD yang saat ini sebagian besar masyarakat dan siswa yang tinggal di Desa Sebudi kurang mengetahui tentang LPD Pakraman Sogra serta peranannya bagaimana. Jika dimungkinkan tanamkan kepada generasi muda (anak-anak) mengenai nilai-nilai karakter dari sebuah LPD Pakraman Sogra yang keberadaanya ada di Desa Sebudi, seperti: Saling menghormati, tolong-menolong, toleransi, tegur sapa sehingga keharmonisan yang telah digagas oleh pendahulu mereka yang akan dilanjutkan pada generasi anak cucu selanjutnya.

3. Sekolah

Bagi sekolah-sekolah yang ada ditengah-tengah masyarakat multikultur hendaknya peduli tentang keberadaan lingkungan masyarakat dan interaksi sehari-hari sebagai sumber materi terutama mata pembelajaran IPS. Sehingga,sumber yang telah ada dilingkungan tidak terbuang secara percuma.

4. Pemerintah

Pemerintah Daerah hendaknya lebih memperhatikan keberadaan masyarakat yang memiliki tradisi-tradisi unik, Organisasi desa seperti keberadaan LPD sebagai

\section{DAFTAR RUJUKAN}

Anantawikrama. 2011. Penyertaan Modal Sosial Dalam Struktur Pengendalian Intern Lembaga Perkreditan Desa (LPD) (Studi Kasus Pada LPD Desa Pakraman Penglatan, Kecamatan Buleleng, Kabupaten Buleleng, Propinsi Bali. Jurnal IImiah Akuntansi Dan Humanika. Vol.1, No.1.

Atmadja, Anantawikrama Tungga. 2013. "Penyertaan Modal Sosial Dalam Struktur Pengendalian Intern LPD (Studi Kasus Lima LPD di Kecamatan Buleleng, Kabupaten Buleleng, Bali)" Jurnal IImiah,

Anantawikrama. 2015. Habitualisasi Sebagai Model Pendidikan Antikorupsi Di Lingkungan Keluarga. Jurnal Ilmiah Akuntansi dan Bisnis Vol. 10, No.2 Tahun 2015. 
Anantawikrama. 2016. Analisis Transparasi Dan Akuntabilitas Sistem Informasi Akuntansi Dalam Pelaporan Keuangan Lembaga Perkreditan Desa (LPD) (Studi Kasus Pada LPD Desa Pakraman Banyuning, Kecamatan Buleleng). Jurnal Ilmiah Mahasiswa Akuntansi S1. Vol.4, No. 1.

Badan Pusat Statistik. 2020. Kecamatan Selat dalam Angka 2020.

Bawa Atmaja, Nengah, Gede Suardana dan I Nyoman Darma Putra. 2018. The Legend Of Balinese Goddesses; Komodifikasi Seni Pertunjukan Hibrid dalam Pariwisata Bali. Modal Budaya Pariwisata Bali. Vol.8 No.1

Darmayanti, Deni. 2014. Panduan Implementasi Pendidikan Karakter di Sekolah. Yogjakarta: Araska.

Gunawan, Rudy. 2011. Pendidikan IPS Filosofi, Konsep dan Aplikasi. Bandung: Alfabeta

Hilmi. 2015. Nilai-nilai kearifan Lokal Dalam Perilaku Sosial Anak-anak Remaja di Desa Sempit Kecamatan Keruak Kabupaten Lombok Timur" terbitan Universitas Negeri Semarang. Journal of Educational Social Studies 4 (1) (2015).

Jampel, I Nyoman, Lasmawan dan Ardana.2017. Evaluation Of Learning Programs And Computer Certification At Course Institute In Bali Using Cse-Ucla Based On Saw Simulation Model. Journal of Theoretical and Applied Information Technology Vol 95. No. 24.

Kurniawan,Kadek Ermanda. 2015. Pemanfaatan Makam Keramat Karang Rupit Syeikh Abdul Qadir Muhammad (The Kwan Lie) Untuk Pengayaan Materi Pembelajaran Ips Di Kelas VII: E-journal Pasca Undiksha vol 1 ( Halaman 123-129): Universitas Pendidikan Ganesha.

Lasmawan, Wayan. 2010. Pendidikan IPS Dalam Perspektif Kontekstual-Empiris. Singaraja: Mediakom Indonesia Press Bali.

Noeng, Muhadjir.2007. Metodelogi Penelitian Kualitatif.Yogjakarta: Rake Sarasin.

Sriartha, I Putu dan Sri Rum Giyarsih. 2015. Spatial Zonation Model of Local Irrigation System Sustainability (A Case of Subak System in Bali). IJG Vol. 47, No.2

Suartana, I Wayan. 2010. "Akuntansi Keperilakuan Teori dan Implementasi”. Yogyakarta: Penerbit Andi.

Soeprapto. 2010. Pembelajaran Ips Terpadu (Studi Kasus SMP Negeri Kabupaten Pati). Tesis tidak diterbitkan. Surakarta: Program Pascasarjana Universitas Sebelas Maret.

Sukmadinata, Nana Syaodih. 2009. Metode Penelitian Pendidikan. Bandung : PT Remaja Rosdakarya. 